\title{
THE RETURN OF THE “SPIRITUAL SOLDIER”: REBECCA WEST’S
}

\section{HENRY JAMES ${ }^{1}$}

\author{
By Rachel Bryan \\ Jesus College, University of Cambridge
}

On $21^{\text {st }}$ February 1914, Rebecca West left London for Hunstanton, a small village on the Norfolk Coast. West was nearly three months pregnant at the time, but made the journey alone; her married lover, the writer H. G. Wells, was to follow in a later train, having deemed it too risky even for the couple to ride in separate compartments (Ray 48). Wells had chosen Hunstanton for Rebecca's confinement on account of its remote location, and had taken pains to segregate his mistress from their London circle and its gossips. The six months West lived in Norfolk were accordingly some of the loneliest of her life, but would also prove highly instrumental in shaping her early literary output. West's short story 'Indissoluble Matrimony' was published in Blast during her Hunstanton exile; and it was in that red-brick seaside house, cut off from London society, that her mind was to turn to the life and work of Henry James, a writer whom her lover had often visited in the comparable setting of Rye. As tensions mounted in mainland Europe, West began work on a critical study of James for Nisbet's 'Writers of the Day' series, and on $4^{\text {th }}$ August 1914 was to find herself subject to a coincidence of personal and national history. A matter of hours after Britain had declared war on Germany, Rebecca gave birth to a son, Anthony Panther West. 
Musing on that fateful day, West would note that she experienced Anthony's first hours "not with the passive contentment of the mother in peace-time, but with the active and passionate intention: 'I must keep this thing safe"” ("Women of England" 7). This attestation of maternal fervor aside, however, West's attitude towards motherhood was ambivalent. Pregnant or not, Rebecca had envisaged herself writing dispatches from the Front when war finally came, and the prospect of hiding away in rural villages "prepar[ing] [her] Citizen for the Age of Peace" did not always appeal (Wells, qtd. in Ray 53). This struggle to reconcile maternal duty with literary ambition remained throughout West's life, and, thanks to her son, would weigh heavily upon her posthumous reputation. Indeed, shortly after Rebecca's death in March 1983, Anthony West would publish two works displaying clear feelings of resentment towards his famous mother: Heritage, a thinly-veiled account of his childhood, ${ }^{2}$ and a biography of his father, $\underline{H}$. G. Wells: Aspects of a Life.

Considering mother and son's antagonistic relationship, the disparaging comments

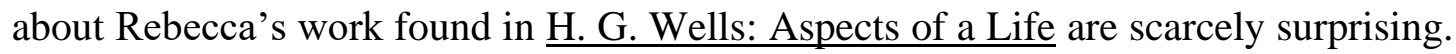
What is curious, however, is how often its diminutive appraisal of her 1916 monograph $\underline{\text { Henry James }}$ has been repeated in subsequent scholarship. Anthony West's commentary does not, after all, approach Rebecca's "first published book" as work of serious criticism (49), but as evidence of the ends to which she had gone to sabotage her relationship with Wells: "Had my mother wished to drive a wedge between [herself and H. G.], she could hardly have hit on a better way of doing it than by publishing this particular book at that particular moment" (50). The problem with Henry James was that within its pages Rebecca had spoken defiantly of "the overriding importance of art and the artist in the universal scheme" (49): a critical 
judgment Anthony saw as tantamount to taking the Master's side over Wells's in their bitter debate on the art of fiction. ${ }^{3}$

Critics have tended to agree with Anthony West that Henry James should be viewed as Rebecca's entry into that infamous debate, reading the monograph as a response to Well's literary satire Boon (1915) and its merciless mockery of the Master in the chapter 'Of Art, Of Literature, Of Mr. Henry James'. Nevertheless, there remains a starling lack of consensus on whether it expounds Wellsian or Jamesian views. Gordon N. Ray asserts that "Rebecca's passionate convictions concerning the importance of art in all its forms" are such that make "Boon and [her] little book on the Master [...] poles apart in their assumptions" (123). Miranda Seymour notes the strong verbal echoes between 'Of Art, Of Literature, Of Mr. Henry James' and West's

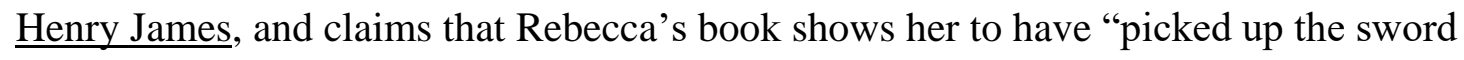
where Wells dropped it in order to deliver another stab to [James's] corpse" (268).

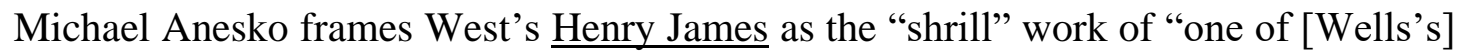
several mistresses", and agrees that its purpose appears to have been to extend the attack begun the previous year in Boon (415); whereas Michael Sherborne implies that West's influence should be seen as responsible for the "outspokenness" of Wells's scandalous book (that provocative tone being the young suffragist's "stock in trade") (223).

One explanation for these contradictory accounts is that West's writings on the Master, like much of her vibrant criticism, mix effusive praise with sardonic, highly metaphorical critique. Those seeking evidence of Jamesian or Wellsian sympathies can easily find it, yet the piece in its entirety is neither so consistent nor limited in its 
approach. Another is that critics choosing to read the monograph as the final act in the Wells/James debate do so amidst uncertainties surrounding the work's compositional history relative to the Jamesian sections of Boon. We know from West's biographer, Victoria Glendinning, that she began her James book in Hunstanton (52): a fact that situates initial work on the monograph as taking place between $21^{\text {st }}$ February and $24^{\text {th }}$ September 1914, even if passing references to James's obituary notices in the published edition suggest that West would continue to update her manuscript until at least March 1916 (117). H. G. Wells had conceived of Boon back in 1901, but Leon Edel and Gordon N. Ray propose that the James chapter was not added to the work until some time after James's essay ‘The Younger Generation' had appeared in March 1914 (36). This claim is supported by a letter Wells wrote to James shortly after Boon's publication on $5^{\text {th }}$ July 1915, in which he describes 'Of Art, Of Literature, Of Mr. Henry James' as the product of wartime anxiety ("writing that stuff about you was the first escape I had from the obsession of this war"), and professes that his return to the earlier Boon manuscript had taken place in December 1914, more than 3 months after Rebecca had left Norfolk (James and Wells 264).

From existing evidence, it would thus seem difficult to justify framing West's Henry James as merely a reply to Wells's literary satire. Nevertheless, those disposed to do so often also overlook the possibility that Rebecca West's critical voice might be anything other than tacitly compliant with the opinions of either Wells or James. It is far more suggestive, and indeed more accurate, to consider West's criticism in terms of the unique subjective position of its author: that of a single mother, an aspiring novelist, and an intelligent woman confronted daily with the fears and frustrations of life on the British Home Front. West's Henry James is a study 
overshadowed by the recent loss of both its masterful subject and of the nineteenth century epoch his oeuvre embodied. But it has value, too, as one of a series of early critical and imaginative works in which West engaged with James's oeuvre from the standpoint of her civilian experience of the Great War: a conflict in whose psychological disquiet she found a need for, and creative resonance with, James's late writings.

West would not remain in Hunstanton long after Anthony's birth. By $24^{\text {th }}$ September 1914, mother and baby had relocated to Hertfordshire, and it was around this time that West was signed up to be a regular contributor to The New Republic when it launched that November. Her piece on 'The Duty of Harsh Criticism' for the first number appeared to neglect James - who had used similar phrasing to critique Wells and the state of contemporary novels in his essay 'The Younger Generation' but just three months later she would engage explicitly with James's critical writings by reviewing Notes on Novelists for the $27^{\text {th }}$ February issue beneath the heading 'Reading Henry James in War Time'. ${ }^{4}$ This, of course, was what West had been doing since August 1914, yet the review was in fact to situate her reading as taking place in the midst of an event unprecedented before 1915: an air raid on British civilians.

The evening of $19^{\text {th }}$ January 1915 had seen the long-expected Zeppelin attacks on Britain finally begin, with two Imperial Navy airships successfully bombing stretches of the Norfolk coastline in a raid that would leave 4 dead and inflict over $£ 7000$ worth of damage. According to contemporary reports, the village of Hunstanton was among the settlements threatened that night ("Airship Over Sandringham" 8); and although we know that West was no longer living in Norfolk at the time, the image of deathly 
airships circling above the rural retreat where she had begun her work on James would seem to have inspired a piece of imaginative and highly personal criticism.

The discussion of Notes on Novelists in 'Reading Henry James in War Time' is framed as the result of an evening when West and a companion had been caught up in a Zeppelin raid, and commences with a similar observation to Charlotte Brontë's Jane Eyre: that darkening skies and a sense of foreboding made it "no time for a walk" (98). Unable to follow government protocol and "descend into a cellar or basement", the women had instead adopted the young Jane's strategy of escaping into a book. "I felt myself supremely fortunate", West declares,

in having Mr Henry James's latest volume, "Notes on Novelists" in the house $[\ldots]$ for a time I hid from fear quite effectually in the branching complexities of aesthetic theory, the intricate undergrowth of subtle perceptions in the volume. (98)

West nevertheless goes on to describe how she arrived at "certain essays of a later date," which denied her "intellectual cover" by being "sealed, as though by strips of gummed paper, by Mr. Henry James’s latest style” (98-99):

[I] tried to send my intelligence winging up beside his soaring phrases, as though their flight was to be followed with composure. But the more I did so the stronger became the conviction that these divagations were not the gambols of a winged intellect in an element over which it had full command, but rather the disordered earthly spirals of wings so overworked that free and happy flight had become an impossibility. (99) 
Comparisons of James's late writings to winged works soaring beyond the scope of mortal intellect were nothing new. J. P. Mowbray's essay 'The Apotheosis of Henry James' from November 1902 had borrowed The Wings of the Dove's eponymous metaphor to describe James's oeuvre as that which with "every new flight [...] required of us larger instruments of observation", not because "the field of vision grew larger, but that the terrestrial light grew less". Mowbray remained content to describe the Master in almost deific terms, but this Jamesian star was one he saw as receding dangerously from the reach of earthly ken: "We hold resolutely to the belief that there are systems somewhere to which Mr. James is an undiminished sun. But they are not ours" (Critical Heritage 326). Such comments, at once laudatory of, and yet vexed by, James's style, were common in reviews of works written after 1901. And it is from this established critical position that West's review appears at times to speak, especially when expressing preference for texts produced before the transition into the late style, and what she likewise identifies as James's purposeful disassociation from the urgent realities of human experience (99).

West might bemoan what she saw as the sublimation of the worldly, human factor in the late writings, but this very issue of mind-forged, intellectual and highly imaginative escape is central to the fabric of James's twentieth century works. What the likes of West and Mowbray identify as "soaring phrases" in flight from the conceptual and embodied realities of life, are in fact the animating principles of texts visibly wrestling with the limits of consciousness, and of those redemptive or compensatory mechanisms available within the mind's creative and interpretive faculties. If we return to James's oeuvre with an eye to the "wings" from which such 
critics begin their own rhetorical flights, we see that the trope often belongs to James's interrogation of what manner of hope possession of a receptive consciousness might offer to those railing against the constraints of finite existence. Milly Theale's dove-like quality reaches its majestic height after her death, when, in making a monetary bequest to Merton Densher despite his betrayal of her, she succeeds in bestowing the gift of herself-as-memory to the mind of this pensive, restless young man: an act Kate Croy likens to that of "stretch[ing] out her wings" (508). And in the final line of James's 1910 essay 'Is there a Life After Death?', protective “wings” are what he suggests might "spread" to cover those able to form certain types of "mental relation": who have learnt to "live increasingly within [their] own consciousness", establishing "speculative and imaginative connections" between themselves and those glimpses of the infinite discernable within mortal life $(609,614)$. Read closely, such moments are not indicative of an artist wholeheartedly advocating an abandonment of the earthly sphere for the sublimating principles of the mind, of art and of beautiful acts. They are part of James's exploration of how far the imaginative realm can compensate for and triumph over experiential constraints, and, equally, how much of what is essential may be lost when one turns one's back on terrestrial things. After all, despite the after-life she is given in Densher's mind, Milly still dies frightened and alone in Venice; Densher might gain a beloved memory, but he loses the vital Kate; and for all his literary prowess, the most James can offer readers of 'Is there a Life After Death?' is a way of thinking about mortality within which immortal hope might yet remain undefeated.

The Rebecca West who writes 'Reading Henry James in Wartime' cannot perceive this complexity, and her inability to do so is partly related to the conceptual airspace 
into which she places those "soaring phrases" encountered in Notes on Novelists. Sending her "intelligence winging up beside" the flight-path of James's prose, West has, in a sense, situated her act of reading within a sky already populated by hostile airships and dogfights: given her air raid conceit, one can scare read of the "disordered earthly spirals" of James's overworked syntax without picturing bombs falling onto their victims, or the circling descent of a biplane. The sky into which the likes of Mowbray had placed James's work had been the domain of majestic stars and blazing asteroids; that over West's head in 1915 was the province of machines created for efficient, ruthless destruction. Indeed, such an "element" was that over which a mind like James's could not profess "command", and within whose barbaric jurisdiction, West implies, any privileging of the refined seemed destined to be shot down.

We gain a glimpse of the profound challenge the war's invasion of once heavenly skies posed to West's theory of aesthetics when we compare 'Reading Henry James in War Time' to her 1926 essay 'Battlefield and Sky'. In that piece, West considers Dickens, Thackeray and Trollope, and declares that they were men whose lives and natures were "battlefields", intense confrontations between themselves and society. Their genius, however, lay in the fact that

over them, like the sky, arched their sense of harmony, their sense of beauty and rest against which their misery and their struggles were an offence, to which their misery and struggles were the only approaches they could make, of which their misery and their struggles were an integral part. (300) 
To be a "considerable artist", West concludes, "[i]t is necessary to have both things, the battlefield and the sky." (300) As noted, it would be hard to read texts like The Wings of the Dove or 'Is there a Life After Death?' without happening repeatedly upon the battlefield at the heart of James's late writings, and the majestic sense of sky that was, perhaps, his most enduring hope. Yet 'Reading Henry James in War Time' seems less concerned with performing an exacting analysis of the impulses behind the late style than offering an account of just how difficult it is to send one's intelligence winging up in pursuit of aesthetic principles that the Great War seemed bent on disavowing.

It is for this reason, however, that the abrupt revision in the final paragraph of West's 1915 review feels so extraordinary:

I had once felt it as an alienating quality of Mr. James's genius that his work showed an inhuman incapacity for enthusiasm [...] But as the throb of the Zeppelin returned and I knew again the helpless rage of the noncombatant, the sick fear of instant death, I realized that enthusiasm was not so necessarily divine as I had thought. For those murderers by intent who were circling above my head in an attempt to locate the lightless town for the purposes of butchery were probably burning with as pure and exalted a passion as they could conceive. This war has shown that every warm passion - loyalty, patriotism, ambition - can be perverted to obscene uses. Nothing is innocent in man except the mind. (100) 
West might scoff at James's apparently Flaubertian aspiration "to tower above life in tranquility, and look down upon it with infinite understanding; to be a god in one's brain" (100), but her understanding of civilian terror is acute enough to acknowledge that when "the sick fear of instant death" returns, "the presence of [James's] marvelous brain, manifested in those innumerable volumes" might "bring such reinforcement to our faith in the intellect as the pious would find in the company of a saint" (100). The Master's magisterial writings might feel irreconcilable with and even inappropriate for a world at war; but they are, by the same token, exactly what a besieged mind most requires: examples of human prowess beyond its aptitude for mindless destruction.

When West's monograph Henry James appeared the following year, it would exhibit few overt debts to 'Reading Henry James in War Time'. The droning Zeppelins are gone, and it is anecdotes from the Master's own life that hold West's attention. "[T]he European War" nevertheless persists on the contextual fringes of the piece, as the conflict against which James lived his final months, paying "kindly visits to French and Belgian refugees and wounded soldiers" and offering "gifts of money and writings to war charities" (117). It is unclear whether West had actually read those of James's wartime essays published before his death, but ignorance as to the full complexity of his feelings about the Great War - that he struggled to write fiction during it, felt its horrors deeply, and yet professed profound admiration for its young servicemen - might partly explain why in Henry James another conflict, the American Civil War, is identified as defining the tenor of James's life and work. According to West, "the whole character of Mr James' genius" was such that could be traced back to his obscure hurt, and the abstention from military service it provided: "If he had 
seen America by the light of bursting shells and flaming forest", she notes, "he might never have taken his eyes off her again, [...] he might have been the Great American Novelist in subject as well as origin" (20). The young Henry painted by West's biographical portrait is one who, invalided out of possibly reifying soldiery, was forced to conceive of an alternative "scheme of existence" within which "the one who stood aside and felt rather than acted acquired thereby a mystic value, a spiritual supremacy" that "would be rubbed off by participation in action" (21).

West's biting prose seems to revel in comparing the "delicate, unpromising" Henry, whose Harvard tutors believed him an "inarticulate mediocrity who would never be able to take a hand in the business of life," to the "brilliant" William, or the courageous Wilky and Robertson (20-21). Yet there is reverence, too, for the man who "in an hour of glowing resignation" could "work out" a superior mode of being within which life's indignities might be artfully redeemed (21). Characterizing James thus in book published in the midst of the Great War, a conflict that he had himself identified as a "sudden leap back into life of the violence with which the American Civil War broke upon us" ("Within the Rim" 11), was not, however, a neutral act. By accident or design, West's monograph sets up James's writing as literature of, and perhaps even for, the non-combatant: an oeuvre forged in opposition to both the carnage and exhilaration of active service. The Master, after all, was one who had transfigured his body into a source of painful empathy with war-torn America "ach[ing]", as he had described himself in Notes of a Son and Brother in "tragic fellowship" with "the enclosing social body, a body rent with a thousand wounds," (415) - yet he had never taken up arms in defense of his country, nor shaken with the fear and adrenaline of combat. 
In a letter he wrote to The Times following his dear friend's funeral, Edmund Gosse had claimed that "[n]o one had suffered more in spirit, no one was more agitated by the war, than Henry James" ("The Funeral of Henry James" 7), and it is this sentiment that West appears to echo when describing, in the final paragraph of her monograph, how the elderly Master had "enlisted" in the Great War as a "spiritual soldier" (117). As a young mother on the Home Front, one might suppose West to be an advocate of spiritual soldiery, and of the recognition this term bestows upon those non-combatants who bore psychic scars of empathetic identification with the horrors across the sea. But she was wary too, as we have seen, that this Jamesian scheme of existence - receptive, imaginative and capable of bringing intense, fanciful experiences to bear on one's emotional life - could as easily be mustered as a means of escaping the pain and civic responsibility produced by wartime as it could be of facing it. The terror produced by the first Zeppelin raid might have been the context through which West came to esteem the products of James's "marvelous brain", but by the time Henry James appeared in spring 1916, the conflict had escalated to such proportions that the British government began taking legislative steps to ensure no able-bodied man could choose spiritual soldiery in favor of signing-up. Indeed, the Military Service Act, which came into force on $2^{\text {nd }}$ March 1916, introduced conscription to unmarried men between the ages of 18 and 45, with a second Act passed in May extending the criteria to include married men.

Perhaps reflecting this further escalation of war into the lives of the civilian populace, West's analysis in Henry James sees her unleash scathing critiques upon the likes of The Awkward Age and The Golden Bowl, behind whose portraits of a world 
in which there is "nothing more dangerous" than the "deer and peacocks" that haunt country parks, and "nothing more damaging to the soul [...] than well-bred women" (106), West suspected not the "spiritual supremacy" of Jamesian art, but an old man's displeasure with modern life. The experience of pain, both psychological and physical, also finds itself instilled with an aesthetic premium in her monograph, as the hallmark of the greatest art and of meaningful human experience. And it is for this reason, it seems, that West finds herself struggling with the romantic retrospection she senses in James's writing, as if it were not a feat of imagination but an act of cowardice to renounce the present age as "a veil of tears", as the elderly Master had apparently done, and pledge allegiance to the superiority of bygone eras (105). According to West, the "later phases" of James's work were shaped by the "illusion" that

the past would have been a happier home [...] He never perceived that life is always a little painful at the moment, not only at this moment, but at all moments; that the wine of experience always makes a raw draught when it has just been trodden out from bruised grapes by the pitiless feet of men, that it must be subject to time before it acquires suavity. (27-8)

Across James's oeuvre we encounter many examples of his receptivity to the persistent, insistent allure of the past, and of the recognition that a desire to recapture an idealized lost time remains an essential if tantalizing constituent of modern consciousness. It is there, for example, in the narrator of The Aspern Papers' relentless pursuit of Juliana's letters, and in Ralph Pendrel's yearning to experience the London of $1820 .{ }^{5}$ Nevertheless, so keen is West to cast James as the romantic fool 
who believes in utopic refuges safe from the onslaught of historical progress, that she overlooks just how often he has disillusionment, failure and loss befall those who characterize the past as a happier home for their discontent. Yet West did not consistently ignore the implications of such stories. A more nuanced recognition of James's complex relationship to the painfulness of being in time, and to what our creative faculties might muster in defiance of it, can indeed be perceived in the work of fiction West would publish in the final months of the war: her debut novel The $\underline{\text { Return of the Soldier (1918). }}$

A tale at whose heart sits the ethical conundrum of whether or not to cure a shellshocked Captain of the amnesia that has robbed him of the last fifteen years of his life, The Return of the Soldier might be seen as the final act of West's own debate with the Master: the work that shows her to have finally come to understand the draw James often represented towards an idealized, emotionally sustaining past. Wounded during the Battle of the Somme, Chris Baldry wakes up believing that the year is 1901, and that he is twenty-one years old and in love with a publican's daughter, Margaret Allington. Sent home to convalesce, Chris is reunited with his cousin Jenny, the novel's narrator, and with Kitty, the wife he knows only as one might "know a woman staying in the same hotel" (48). Not content until he sees his first love again, Chris successfully appeals to Jenny to summon Margaret, who returns to Baldry Court "repulsively furred with neglect and poverty" (15). Chris, however, takes up with her again as if no time had passed. Their love becomes part of what Jenny calls the "magic circle" of Chris's amnesia (109): a saving mechanism that soothes his lovestarved soul and protects him from being sent back to "the hell of war" (111). 
Looking back over Chris's life, Jenny observes that he never had been "like other city men" (11). As a boy, he had expected adventures to befall him "with a stronger motion of the imagination than the ordinary child's make-believe", and in adult life this faith had persisted, becoming "the hopeless hope that some time he would have an experience that would act on his life like alchemy, turning to gold all the dark metals of events" (12). As snippets of a case history, such details add to the realism of West's psychological portrait; but they also paint Chris as heir to figures from James's late works whose malcontent is revealed within and counterpointed by a rich mental world. His "hopeless hope" for a single alchemical experience has parallels with John Marcher's “sense of being kept for something rare and strange, possibly prodigious and terrible" in 'The Beast in the Jungle' ( $\underline{\mathrm{CS}}$ 503); and, like Spenser Brydon of 'The Jolly Corner', Chris is one who has spent his life seeking an illusive sense of fulfillment that finds itself figured as a yearned for re-encounter with a model of happiness forsaken years before.

Yet of all the Jamesian echoes in The Return of the Soldier, perhaps most illuminating is that which places Chris Baldry in dialogue with Merton Densher from The Wings of the Dove, a novel West had herself called a "masterpiece" (프 104). Chris shares with Merton a vibrant mental life within which "thoughts" can "thril[1] him almost like adventures" (WD 428); and Kate's accusation to Densher in the final moments of that novel that he is "in love with" a memory might equally be leveled against Captain Baldry ( $\underline{\text { WD }}$ 509). Unlike Milly Theale, the object of Chris's affection is not dead, but nor is the version of Margaret he loves so ardently alive in the sense of performing an identity independent of that dictated by her lover's psychological needs. After all, the conditions of Chris's amnesia are such that he 
cannot recall those times when Margaret brought him displeasure: the occasion he caught her "larking" in a rowing boat with a local "bounder", or the realization that he couldn't trust her "as he would trust a girl of his own class" (80). In offering no resistance to this blissful narrative of their past, Margaret protects Chris not only from the horrors he saw at the Front, but also from the worldly pressures against which his decision to leave her was enacted. His amnesiac's mind is, truly, a "magic circle" existing in defiance of what Jenny calls "the cruelty of the order of things" (123): a protected, protective space of psychological nourishment not unlike the rooms within which Densher attempts to guard the "faint far wail" emitted from his figurations of Milly's loss from those hostile "sounds of life" threatening to "smother" and “deaden" it (502).

In contrast to Chris's restful forgetfulness is Kitty, who drifts through her marital home with "all her loveliness diverted to the expression of grief" (135). Beautiful, manipulative and helplessly enamored of things, Kitty feels at times like West's version of the scheming, "envious" Kate Croy she had met in the pages of The Wings of the Dove (HJ 103). Yet her suffering, performed not with Kate's stoic grace but with near hysteria, is nevertheless what convinces Jenny that Chris cannot be permitted to remain enthralled to his delusions. Kitty may be "the falsest thing on earth", but her tears prove that she has faced head-on the desolation of her happiness, and as such remind Jenny that "when one is adult one must raise one's lips to the wine of the truth, heedless that it is not sweet like milk but draws the mouth with its strength, and celebrate communion with reality" (136). Insisting that her husband be cured and returned to her, Kitty is after all also insisting that he recognize and share the burden of the great and terrible things that have happened to them as a couple, the 
most profound of which is the death of their young son Oliver, robbed of life by a chill five years earlier (121). Yet Chris's duty to return to the wife with whom he shares this loss, as it is constructed in West's narrative, resonates as well with his obligation to Britain, and the country's many sons who were daily being sacrificed on the fields of France. His responsibility to his marriage, his country and the pain of reality eventually prevails over Chris's chance "to live in the interminable enjoyment of his youth and love" (135). Under the guidance of a psychoanalytic doctor, Margaret eventually agrees to hand Chris a selection of Oliver's possessions that, revitalizing his memory, cast him out of his amnesiac's Eden.

The novel ends with Jenny and Kitty peering out of a window at the recovered Chris as he marches away from Margaret. "He walked", Jenny observes, "not loose limbed like a boy, as he had done that very afternoon, but with the soldier's tread hard upon the heel" (140). Confronted with this scene, we might be tempted to read Chris's instantaneous recovery and swift adoption of his military persona as indicative of the patriotic, almost propagandistic, form into which West's conflicted novel naively resolves itself. Yet to do so would be to overlook both the haunting pathos of Jenny's final observations, and the implications of the complex type of Jamesian influence I have traced. Knowing that soon after her arms are lifted from Chris's shoulders "he would go back to that flooded trench in Flanders under that sky more full of flying death than clouds, to that No Man's Land where bullets fall like rain on the rotting faces of the dead" (140), Jenny looks upon her cousin's return with a mournful gaze. It is one that has learnt from James's late fiction of the loss than accompanies any choice between the sustaining fictions of the mind and active participation in a bewildering world. The Master's own abrupt ending to The Wings of the Dove may 
have left its sensitive hero in love with a memory, attempting to resist the clamorous sounds of life, but James's vision acknowledged what was sacrificed in Densher's retreat from Kate and the vitality she embodied. West's novel might reverse this ending, but it does not refute it; Jenny supports Chris's recovery, but knows that the protective bliss from which she has snatched his mind and body must be grieved for. Rebecca West spent much of the Great War writing combative and dynamic criticism on Henry James that struggled to reconcile his work with the demands placed upon her as a reader living in the midst of global conflict. Yet by the time The Return of the Soldier appeared, it seems that she had finally come to sense something of the great and costly battle raging at the heart of James's late works, and how his celestial art might still speak to readers living with both terror and conviction under deathly skies.

\section{NOTES}

1 This research was supported by the Arts and Humanities Research Council [grant number AH/L503897/1]. An early version of this paper was presented at the 'The Fictional First World War: Imagination and Memory Since 1914' conference at the University of Aberdeen, April 2017, and was additionally supported by the Faculty of English, University of Cambridge's Graduate Funding Committee. I am grateful to Tamara Follini for her help and encouragement of this piece.

2 Heritage contains a portrait of an inattentive and wantonly irresponsible mother whose resemblance to Rebecca was stark enough for her to initiate legal proceedings against the work. Whilst unable to supress the novel's release in America - it appeared there in 1955 she did succeed in preventing its publication in Britain during her lifetime (Glendinning 203$6)$.

3 Since first meeting in 1898, Wells and James had never seen eye-to-eye on the art of fiction. Wells believed that a novel's artfulness could be subordinated to its social message, 
whereas James had always maintained that art was itself the only valid means of preserving and expressing human experience (Wells and James 11). Their public debate on this issue began March 1914 following the appearance of the first instalment of James's 'The Younger Generation', a two-part essay on the state of contemporary fiction in which Wells and Arnold Bennett were cited as practitioners of novels lacking in balance and compositional rigor, and would culminate in the publication of Boon in July 1915.

4 'The Duty of Harsh Criticism' appeared on $7^{\text {th }}$ November 1914, and saw West bemoan the manner in which Wells's novel The Passionate Friends (1913), a potential "boat of wisdom", could spring "so disastrous a leak" and yet "receiv[e] not one world of abuse from English criticism". "No one", she declared, "lamented over the waste of the mind, the spilling of an idea" (20). About eight months earlier, however, James's 'The Younger Generation' had appeared in the TLS containing passages highly critical of The Passionate Friends and rhetoric almost identical to West's: he had noted both "the fondly neglected state of leakage" in which Wells had assembled the "material" of the novel and the "witnessed pang of waste" that a sensitive reader would be confronted with (James and Wells 190). In reviewing Notes on Novelists for The New Republic three months later, West could not avoid the revised version of 'The Younger Generation' which appeared there as 'The New Novel'.

5 West could not have read The Sense of the Past prior to writing her monograph, as editions of that unfinished work did not appear until 1917. However, those familiar with that novel will know that even with his occult knowledge of the Midmore family, Ralph finds himself far from at home in 1820 . 
WORKS CITED

WORKS BY HENRY JAMES

---. The Aspern Papers and Other Stories. Ed Adrian Poole. Oxford: Oxford University Press, 2013. Print.

---. Autobiography: A Small Boy and Others, Notes of A Son and Brother, The Middle Years. Ed. Frederick W. Dupee. London: W. H. Allen, 1956. Print.

CS --. Complete Stories 1898-1910. Ed. Denis Donoghue. New York: Library of America, 1996. Print.

---. Henry James and H. G. Wells: A Record of their Friendship, their Debate on the Art of Fiction and the Quarrel, Ed. Leon Edel and Gordon N. Ray. London: Rupert Hart-Davis, 1958. Print.

---. "Is there a Life After Death?" The James Family: Including Selections from the Writings of Henry James Sr., William, Henry and Alice James. Ed. F. O. Matthiessen New York: Alfred A. Knopf, 1947. 603-14. Print.

---. The Sense of the Past. London: W. Collins Sons \& Co. LTD, 1917. Print.

WD --. The Wings of the Dove. Ed. Peter Brooks. Oxford: Oxford University Press, 2009. Print. 
---. Within the Rim and Other Essays. London: W. Collins Sons \& Co. LTD, 1918. Print.

WORKS BY REBECCA WEST

---. "Battlefield and Sky." The Strange Necessity: Essays and Reviews. London: Jonathan Cape, 1928. 291-301. Print.

---. "The Duty of Harsh Criticism.” The New Republic 7 Nov. 1914: 18-20. UNZ.org. Web. 1 Aug. 2017.

HJ --. Henry James. London: Nisbet \& Co., 1916. Print.

---. "Reading Henry James in War Time”. The New Republic 27 Feb. 1915: 98-100. UNZ.org. Web. 23 Feb. 2017.

---. The Return of the Soldier. London: Virago Press, 2010. Print.

---. "Women of England.” Atlantic Monthly Jan. 1916: 1-11. UNZ.org. Web. 16 Feb. 2018.

OTHER WORKS CITED

“Airship Over Sandringham”. Times [London] 20 Jan. 1915: 8. Times Digital Archive. Web. 17 Aug. 2017. 
Anesko, Michael. "Critical Response, 1916-1947”. Henry James in Context. Ed. David McWhirter. Cambridge, Cambridge University Press, 2010. 412-22. Print.

Brontë, Charlotte. Jane Eyre. 1996. Ed. Michael Mason. London: Penguin 2003. Print.

Gard, Roger. Henry James: The Critical Heritage. London: Routledge \& Kegan Paul, 1968. Print.

Glendinng, Victoria. Rebecca West: A Life. London: Weidenfeld and Nicolson, 1987. Print.

Gosse, Edmund. "The Funeral of Henry James". Times [London] 4 Mar. 1916: 7. Times Digital Archive. Web. 17 Aug. 2017.

Ray, Gordon N.. H. G. Wells and Rebecca West. London: Macmillan, 1974. Print.

Seymour, Miranda. A Ring of Conspirators: Henry James and his Literary Circle 1895-1915. London: Hodder \& Stroughton, 1988. Print.

Sherborne, Michael. H. G. Wells: Another Kind of Life. London: Peter Owen, 2012. Print.

West, Anthony. H. G. Wells: Aspects of a Life. London: Hutchinson, 1984. Print. 